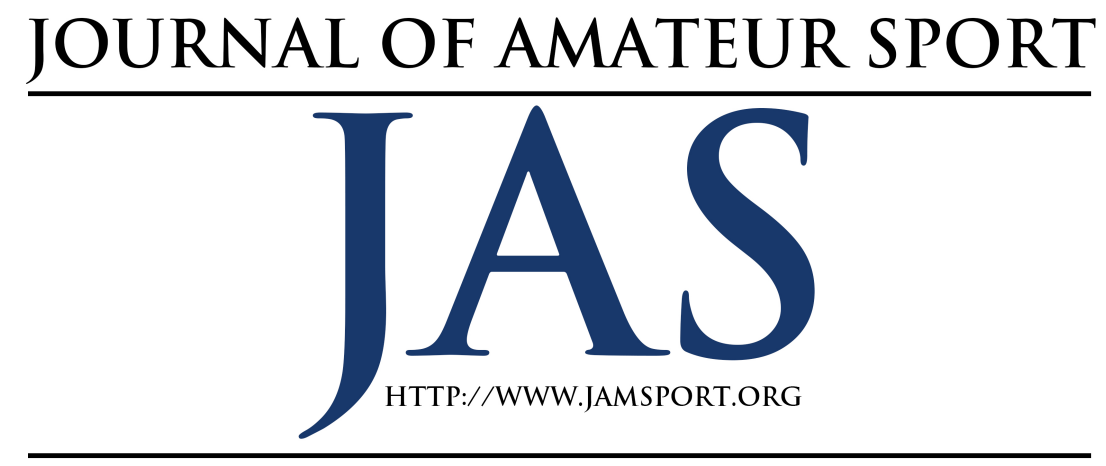

\title{
Sport Discontinuation: An Assessment of Goal Achievement via Empirical Measures
}

\author{
John Patrick Marsh ${ }^{1} \quad$ Jeffrey C. Petersen ${ }^{1}$ \\ Barbara Osborne ${ }^{2}$ \\ ${ }^{1}$ Baylor University \\ ${ }^{2}$ University of North Carolina
}

\begin{abstract}
Collegiate athletic teams are being eliminated at an alarming rate; however, empirical research of athletic spending and participation after these cuts occur is lacking. This study compared whether the proffered rationales for discontinuing teams were consistent with the measurable budgetary and participation outcomes. From a sample of NCAA Division I institutions that discontinued at least one team between the academic years $2000-01$ and 2008-09 $(N=125)$, a total of 49 schools with documented cut rationales were identified. The EADA cutting tool was then used to examine athletic revenues, expenses, and participation numbers from the year prior and the year after the cuts to determine, via descriptive statistics and paired $t$-tests, if the stated objectives were met. The three reasons primarily cited for the program elimination included: reducing athletic spending (44.9\%), reallocating resources $(42.9 \%)$, and Title IX compliance (18.4\%). Statistical analysis revealed that only institutions citing reallocation of athletic resources were able to achieve their stated goals. Institutions citing efforts to reduce athletic spending had significant increases in athletic expenses and none of the institutions citing Title IX compliance achieved substantial proportionality. These results show a troubling disconnection between the sport elimination rationale and the budgetary and participation outcomes.
\end{abstract}

$\mathrm{T}$ he decision to discontinue a collegiate athletic team is one of the most difficult decisions that an athletic administrator must make. Such a decision has life altering implications for many student-athletes and coaches. Thus, it is of the utmost importance that these decisions be made with the best information available. Currently, when the decision to discontinue an athletic program is made 
there is a great deal of analysis and discussion leading up to the decision, but very little follow-up to determine the results of the discontinuation. The lack of followup studies to examine the results of such cuts hinders the ability of future athletic administrators to make the best decision in future situations.

The American economy is always in flux. In light of the recent significant economic downturn and facing uncertainty about the breadth of the recovery, college athletics programs are facing tough questions about their economic futures. All but one of the NCAA Division I institutions, Grand Canyon University, are non-profit institutions (New, 2014). This means that there is little incentive to having expenses greatly lagging behind revenues. Most athletic departments align their spending to utilize nearly every dollar that they make and in most cases institutions are unable to generate enough revenue to cover all of their expenses. In 2009, only 14 of the 120 NCAA Division I Football Bowl Subdivision (FBS) schools reported athletic revenues in excess of athletic expenses as opposed to 25 programs in 2008 (Fulks, 2010). This type of economic uncertainty and challenge for athletic departments is not only a long-term issue, but something that can rapidly change on a year-to-year basis. In 2011 and 2012, 23 FBS athletic programs reported generating revenues in excess of their expenses; however, it was not the same 23 schools in both years (Fulks, 2013). Collegiate athletic departments typically plan for future expenses based on projections of revenues several years in advance. In the face of the economic crisis of 2008, most of these projections did not account for a prolonged economic recession and consequently revenues often began to run far short of projections (Associated Press, 2010). Given such a challenging set of circumstances, what action can be taken by Division I athletic departments?

When revenues come up short, schools must seek ways to contain expenses. Cost cutting measures such as reducing travel per diems, taking longer bus trips rather than fly, and scheduling opponents closer to home are becoming prevalent in college athletic departments. None of these measures, however, take into account the two largest expenses associated with collegiate athletics, coaching salaries and scholarships (Brady, 2009). While scholarships and salaries account for the two largest expenses for NCAA Division I athletic departments (Fulks, 2013), they can be very difficult to control or reduce due to legislative or legal constraints. From a legislative perspective, the NCAA bylaws for Division I member schools include requirements to provide certain minimum levels of financial aid to student-athletes (NCAA Division I Manual, 2015). The scholarships costs are also subject to the current trends of tuition costs for all students, and the cost of college tuition is increasing at a rate four times faster than the consumer price index (Jamrisko \& Kolet, 2014). Prior efforts to control escalating coaching costs have been met with legal action, when United States District Court Judge, Kathryn H. Vratli, ruled that any organized structural restriction on the compensation of coaches violated the Sherman Antitrust Act (Law v. NCAA, 1995). Given these constraints related to making reductions in the number of athletes 
or in coaches' salaries, other solutions to the financial challenges must be considered.

When an athletics program's expenses far outweigh its revenues, one possible solution is to cut teams, as this measure can simultaneously address expenses in both the scholarship and salary budgetary components while sidestepping the aforementioned concerns. From 2007 through 2009, more than 227 varsity athletic teams at NCAA institutions across all divisions were cut (Watson, 2009). In every instance, the decision to cut an athletic program was a complex one that affected the lives of numerous people.

The elimination of collegiate athletic teams is a process that often draws public attention and at times criticism. Therefore, the announcement of such cuts is often publicly communicated with a clear rationale for the cuts as noted in the examples above. However, there has not been specific investigation made after these cuts to see if the budgetary or gender equity outcomes align with the previously stated rationales for the program cut. Therefore, this study was developed to document the stated rationale for cutting teams at the NCAA Division I level, and then to examine these programs after the cuts from both a budgetary and gender equity perspective in the year preceding and the year after the cuts were made. In order to better understand the nature of athletic cuts and the financial and gender equity constraints in collegiate sport, a brief review of pertinent literature of these topics is provided.

\section{Revenues and Expenses in Intercollegiate Athletics Programs}

The factors leading to the discontinuation of collegiate athletic teams have been documented in both academic research and in the media. In a recent study examining the decision making process in intercollegiate athletic departments when eliminating multiple varsity sport programs, four main factors were cited for eliminating teams: an athletic department budget shortage, broader institutional financial constraints, the financial strain of individual teams, and Title IX and gender equity implications (Skolnick, 2011). The first three of these factors relate strictly to budgetary or economic issues while the Title IX factor relates to compliance with federal legislation.

Several recent incidents of Division I program cuts exemplify these rationales. At the conclusion of the 2009-2010 academic year, Cal State Fullerton announced the termination of its wrestling and women's gymnastics teams as a cost saving measure ("Wrestling, Gymnastics Programs Terminated”, 2011). In March of 2011, Liberty University announced that they would be reclassifying their wrestling program from a fully funded varsity sport program to club status. According to Liberty Director of Athletics Jeff Barber, this move was made in an effort obtain compliance with Title IX ("Liberty to Reclassify", 2011). At the conclusion of the 2013-2014 academic year, Temple University eliminated five athletic programs in an effort to produce a "more sustainable experience" for their student-athletes (“Temple Reduces Varsity Sports", 2013). 
The decision to discontinue an athletic team inherently has financial ramifications. In order to better understand these decisions, it is important to analyze the economic climate in which these decisions are being made. The recent economic recession affected nearly every industry in our nation, including college athletics, and the recovery from recessions is becoming an increasingly lengthy process (Olney \& Pacitti, 2015). The fluctuations in the American economy are reflected in the fluctuations in collegiate athletic budgets. Daniel Fulks (2010, 2013) of Transylvania University released two comprehensive reports spanning the 2004-2012 fiscal years. These reports provided valuable insight into the changing fiscal environment in which intercollegiate athletics programs operate.

NCAA Division I is divided into three subdivisions for football, yet, compete as a whole in all other sports. The financial resources for Football Bowl Subdivision (FBS) institutions are much greater than those of Football Championship Subdivision (FCS) institutions and Division I institutions without a football program. The large disparity in financial resources amongst Division I institutions creates a unique competitive landscape in which these institutions must operate. Despite the stark differences in financial resources, fluctuations in athletic budgets is a common theme among all three subdivisions. While revenues increased each year from 20042012, the percent increase varied greatly from year to year (Fulks, 2013). This creates a significant challenge for administrators that project budgets years in advance (Associated Press, 2010). Mean revenues and expenses for each subdivision can be found in Tables 1-3.

The main sources of revenue for athletic departments vary greatly across Division I. FCS and non-football Division I members rely much more on institutional support for revenue, while FBS institutions receive institutional support at levels similar to their revenue generated by ticket sales, contributions from alumni and others, and NCAA and conference distributions. The top expenses, however, are very similar across all three subdivisions. Salaries and benefits are the top expense in each division and student-athlete grant-in-aids are the next greatest expense in each subdivision. A summary of top sources of revenue and expenses are noted in Table 4.

\section{Title IX}

When athletics administrators decide to eliminate teams and thereby participation opportunities for student-athletes, the legal requirements of Title IX of the Education Amendments of 1972, forbidding sex discrimination in any program conducted by a federally funded educational institution, should be considered. Title IX, as applied to athletics, requires schools to provide equal opportunities in three areas: scholarships (or financial aid), treatment, and participation. In 1979, the Office of Civil Rights (OCR) issued a Title IX Policy Interpretation, which introduced a three-part test to measure participation compliance. If an institution is in compliance with any one of the three prongs then that institution is deemed to be effectively accommodating the interests and abilities of its student athletes. The three-pronged test is structured as follows: 
1. The competitive opportunities are provided in numbers substantially proportionate to the respective enrollment of each sex.

2. The institution's current and historical practices of program expansion are responsive to the athletic interests of the underrepresented sex.

3. The institution accommodates the interests and abilities of the underrepresented sex in the current athletic program (Policy Interpretation, 1979).

While compliance with any one of the three prongs allows an institution to be compliant with the law; the proportionality test garners the most attention. The proportionality test has been described by the courts as a "safe harbor" for compliance (Cohen v. Brown University, 1992).

The discontinuation of athletic programs is an all too common occurrence and the process leading up to these discontinuations is relatively well documented. There is, however, a lack of research examining the outcomes of these discontinuations. The purpose of this study was to compare whether the proffered reasons and goals for discontinuing athletic teams expressed in the news media were consistent with the actual measurable outcomes observed after the discontinuation of the teams related to budgetary and gender equity considerations. Based upon the identified problem and purpose, three primary research questions were developed to structure the study:

1. What are the primary, publicly stated reasons given by athletic departments for the discontinuation of athletic teams?

2. What are the financial and participatory outcomes of the discontinuation of athletic teams?

3. Do the financial and participatory outcomes of the discontinuations align with the publicly stated reasons given by the athletic departments?

\section{Methodology}

In order to compare reasons and goals given for the discontinuation of athletic teams in publicly released statements with actual participation and financial information, multiple methods were employed, including content analysis of primary sources for rationale determination and statistical analyses of the financial data and student-athlete participation data.

The population of this study included all NCAA Division I institutions that have discontinued at least one varsity athletic program between the 2001-2002 and 20082009 academic years. The original timeframe desired for this analysis was the entire decade of the 2000s; however, one key data source was not archived before 2001.

The data for this study were collected through a variety of sources by a single primary researcher. First, a list of discontinued athletic teams was obtained through correspondence with the NCAA. From that list, Division I institutions having discontinued at least one athletic team between the 2001-2002 and 2008-2009 academic years were identified. An extensive Internet search for news articles regarding the discontinuation of the identified athletic teams was conducted. Identified institutions 
and athletic teams were searched using Google. The searches were conducted using the institution name, the discontinued sports identified, and the following keywords: discontinued, eliminated, and cut. Content analysis of the obtained news articles was used to identify the publiclystated reasons for the respective discontinuations. The articles were read, content analyzed, and coded based upon key words, phrases, and other textual elements to determine the publicly stated reasoning for the discontinuation of each program.

The methods for research question two required the collection and analysis of financial data and sport participation data for the institutions that discontinued athletic teams. Using the United States Department of Education Equity in Athletics Data Analysis Cutting Tool, data for the institutions having been identified as having discontinued at least one athletic team and for which a news article was obtained was collected. In 1994, Congress enacted the Equity in Athletic Disclosure Act (EADA), to determine if institutions were in compliance with Title IX requirements. The EADA requires that co-educational institutions of postsecondary education that participate in a Title IV, federal student financial assistance program, and have an intercollegiate athletic program, prepare an annual report to the Department of Education on athletic participation, staffing, and revenues and expenses, by men's and women's teams (Equity in Athletics Disclosure Act, 1994). The EADA cutting tool provides public access to the data that is archived back to the 2000-2001 academic year.
The collected data included the male to female ratio of the student body and the male to female ratio of student-athletes. This was used to assess the loss in participation opportunities and compliance with Title IX through proportionality. Financial variables assessed included total athletic revenues and expenses, and the total revenues and expenses for football (when applicable), men's basketball, and women's basketball teams for the year prior to the discontinuation, the year of the discontinuation, and the year after the discontinuation. These variables were chosen to analyze the financial impact of the discontinuations. Football and basketball were specifically chosen due to their status as both primary revenue producers and top spectator sports. It is important to note that revenues and expenses are being analyzed separately from one another. Analyzing revenues and expenses as a combined variable, profit, is not appropriate for this study as all of the institutions in this study are non-profit institutions. Division I athletics is not a traditional business environment where increased profit is the goal for shareholders, but rather a generation of revenue to allow for more spending on the sport enterprise itself.

IBM SPSS version 21.0 and Microsoft Excel were used to analyze the data. Descriptive statistics and primary frequencies were analyzed to determine the primary reasons given for the discontinuation of athletic teams and to examine the financial and participatory data. Paired sample $t$-test analyses were used to assess changes in financial and participatory data from the year prior to the 
discontinuation of an athletic team to the year after the discontinuation.

For the final research question, data from the year prior to the discontinuation of the athletic team(s) was compared to the year following the discontinuation. The observed changes in financial measures of revenues and expenses along with participation rates for men and women were then compared to the publicly stated reasons and goals for the discontinuation to determine if the empirical data was consistent with the rationale.

\section{Results \\ Description of the Sample}

A total of 125 Division I institutions were identified as having discontinued at least one athletic team between the 20012002 and 2008-2009 academic years. Of the 125 institutions, news articles about the discontinuation were obtained for 49 of the institutions $(39.2 \%)$. Of the 49 institutions for which data was obtained, 14 (28.6\%) were Football Bowl Subdivision (FBS) members, 20 (40.8\%) were Football Championship Subdivision (FCS) members, eight $(16.3 \%)$ were non-football playing members, and seven $(14.3 \%)$ were FCS members eliminating their football programs.

As shown in Table 5, the 49 institutions for which data was collected combined to eliminate 95 programs. Of these 95 programs, 66 (69.5\%) were men's programs. This shows that men's programs were being eliminated at more than twice the rate of women's and co-ed programs combined. Table 1 also appears to show an increase in the number of programs being cut over time, but it is important to note that changes in webpage archiving practices caused the recovery of articles from earlier years to be more difficult. Table 6 shows the breakdown of the number of programs eliminated per institution. A total of 40 $(81.6 \%)$ of the institutions in the study eliminated either one or two programs; however, as many as 10 programs were eliminated at one $(2.0 \%)$ institution.

Three primary reasons and five secondary reasons for the discontinuation of athletic teams were identified in the news articles. The three primary reasons identified for the discontinuation of athletic teams were efforts to reduce athletics spending, the reallocation of athletics resources, and Title IX compliance. The five secondary reasons identified for the discontinuation of athletics teams were the lack or loss of a conference to compete in, poor academic performance of the team, lack of competitiveness of the team, lack of facilities for the team, and poor experiences provided to the team's student-athletes.

Efforts to reduce athletics spending was the most frequently stated reason for the discontinuation of athletic teams having been stated by 22 of the 49 institutions $(44.9 \%)$. The reallocation of athletics resources was a stated reason for the discontinuation of athletic teams by twentyone $(42.9 \%)$ of the institutions. Title IX compliance was a stated reason for the discontinuation of athletic teams in nine $(18.4 \%)$ of the institutions. Of the five secondary reasons for the discontinuation of athletic teams, the lack or loss of a conference to compete in was stated by five $(10.2 \%)$ institutions, poor academic performance of the team was stated by two $(4.1 \%)$ of the institutions, lack of 
competitiveness of the team was stated by two $(4.1 \%)$ of the institutions, lack of facilities for the team was stated by two $(4.1 \%)$ of the institutions, and poor experiences provided to the team's studentathletes was stated by one $(2.0 \%)$ institution. It should be noted that multiple rationales were recorded for many schools resulting in cumulative percentages greater than 100 .

\section{Participatory and Financial Data}

The 49 institutions in this study saw a significant mean loss of 35 male student athletes from the year prior to the discontinuation to the year after the discontinuation, $\left.t_{(48)}=4.499, p<.001\right)$ The mean losses of male student athletes for each of the three sub-groups of primary reasons for the discontinuation of an athletic program were also statistically significant. Neither the 49 institutions as a whole nor any of the three sub-groups saw statistically significant changes in female student athletes. The complete participatory data can be found in Table 7 .

When the 49 institutions included in this study were examined as a whole, total expenses $\left(t_{(48)}=6.215, p<.001\right)$, football expenses $\left(t_{(35)}=3.377, p=.002\right)$, men's basketball expenses $\left(t_{(48)}=5.148, p<.001\right)$, and women's basketball expenses $\left(t_{(48)}=\right.$ $4.266, p<.001)$ increased at statistically significant levels from the year prior to the discontinuation of athletic teams to the year after the discontinuation. Total revenue $\left(t_{(48)}\right.$ $=3.866, p<.001)$, football revenue $\left(t_{(25)}=\right.$ $3.036, p=.005)$, and women's basketball revenue $\left(t_{(48)}=2.359, p=.022\right)$ also increased at statistically significant levels. The complete financial data for the sample as a whole can be found in Table 8 .
From the sample, 22 institutions cited efforts to reduce athletic spending as a primary reason for the discontinuation of athletic teams. These institutions had statistically significant increases in total athletic revenue $\left(t_{(21)}=4.027, p=.001\right)$, and total athletic expenses $\left(t_{(21)}=4.019, p=\right.$ .001). It is important to note that while both revenues and expenses increased significantly, total revenues $(17.2 \%)$ increased at a greater rate than total expenses $(11.8 \%)$. Men's basketball expenses $\left(t_{(21)}=2.129, p=.040\right)$ also increased at a statistically significant rate and while the increase in men's basketball expenses was 35\%, this was not found to be significant at the .05 level. Summary financial data for institutions citing efforts to reduce athletic spending can be found in Table 9.

Twenty-one institutions cited the reallocation of athletic resources as a primary reason for the discontinuation of athletic teams. Statistically significant increases were found for both the mean total revenues $\left(t_{(20)}=3.920, p=.001\right)$ and mean total expenses $\left(t_{(20)}=3.580, p=.002\right)$ for these institutions. Increases in mean football expenses $\left(t_{(13)}=2.489, p=.027\right)$, mean men's basketball expenses $\left(t_{(20)}=\right.$ $4.512, p<.001)$, and mean women's basketball expenses $\left(t_{(20)}=3.739, p=.001\right)$ were also statistically significant. It is also important to note that from the year prior to the discontinuation of athletic teams to the year after the discontinuation, these institutions saw an increase in mean athletic expenses of $\$ 2,111,141$. Of this, $\$ 1,277,215$ $(60.5 \%)$ consisted of increases in football and men's basketball expenses. The financial data for institutions citing the 
reallocation of athletic resources can be found in Table 10.

Nine institutions identified Title IX compliance as a primary reason for the discontinuation of athletics teams. In the year prior to the discontinuation, these institutions had a mean of $44.67 \%$ male students and a mean of $58.22 \%$ male student athletes. In the year following the discontinuation, these institutions had a mean of $45.11 \%$ male students and a mean of $54.00 \%$ male student athletes. Of the nine institutions citing Title IX compliance, none achieved direct substantial proportionality, two $(22.2 \%)$ came within two percentage points of direct substantial proportionality, five $(55.6 \%)$ came between five and ten percentage points of direct substantial proportionality, and two $(22.2 \%)$ did not come within ten percentage points of direct substantial proportionality.

Among the nine institutions citing Title IX compliance as a primary reason for the discontinuation for athletic teams, mean total athletic revenue $\left(t_{(8)}=3.052, p=.016\right)$, mean total athletic expenses $\left(t_{(8)}=3.011, p\right.$ $=.017)$, mean men's basketball revenue $\left(t_{(8)}\right.$ $=2.781, p=.024)$, and mean men's basketball expenses $\left(t_{(8)}=3.069, p=.015\right)$ were all statistically significant. Increases in football and men's basketball expenses from the year prior to the discontinuation to the year after the discontinuation totaled $\$ 1,717,742$. This accounts for $56.0 \%$ of the $\$ 3,065,492$ increase in total athletic expenses. Table 11 shows the complete financial data for institutions citing Title IX compliance as a primary factor for the discontinuation of athletic teams.

The 22 institutions citing efforts to reduce athletic spending as a primary reason for the discontinuation of an athletic team reported a mean increase in total athletic expenses of $\$ 2,015,476\left(t_{(21)}=4.019, p\right.$ $=.001)$. Such an increase in expenses is not consistent with effective reductions in spending. The 21 institutions citing the reallocation of athletic resources as a primary reason for the discontinuation of an athletic team reported mean increases in total athletic revenues of $\$ 2,221,507\left(t_{(20)}=\right.$ $3.920, p=.001)$ and $\$ 2,111,141\left(t_{(20)}=\right.$ $3.580, p=.002)$ in total athletic expenses. The similarity in the increases in both total revenues and total expenses following the discontinuation of an athletic team is indicative of the reallocation of athletic resources. Of the nine institutions citing efforts to become compliant with Title IX, none achieved direct substantial proportionality. Additionally, from a financial perspective on gender equity, $56 \%$ of the increase in total athletic expenses were allocated to football and men's basketball programs. These participatory and financial outcomes are not consistent with Title IX compliance.

\section{Discussion}

The results of this study are valuable in supporting prior research identifying rationales for athletic cuts at the Division I level. More importantly, the assessment of specific participation and financial indicators pre and post-discontinuation provide empirical measures of the outcomes of sport elimination that have not been reported in the past. The direct comparison of the measured outcomes with the originally stated rationales for the program cuts raises many questions due to the lack of consistency between the rationales and 
observed outcomes. Indeed, the disconnect between the stated rationales and the observed outcomes indicates not only the inability of sport discontinuation to achieve the stated goals, but also a possible political staging of rationales to provide a more palatable rhetoric to the public. A more thorough discussion of these results structured upon the three research questions of this study provides valuable insight into these cuts.

\section{Primary Reasons for the Discontinuation of Athletic Teams}

For research question one, the findings from this study of three primary cut rationales (reducing athletic spending, reallocating resources, and Title IX compliance) aligned well with the prior research of Skolnick (2011) that cited four influential reasons in rank order of Athletic Department Budget Shortage, Institutional Financial Constraints, Title IX/Gender Equity Implications, and Financial Strain of Individual Programs. An assessment of the two most prevalent responses from Skolnick revealed that both involved the reduction of spending. For the purposes of the present study, no distinction was made between the reasons for budget constraints, and this would in effect combine the first two categories of the Skolnick study. Institutions seeking to reduce athletic related spending due to athletic budget shortages and those due to institutional budget constraints were all grouped together. As expected, this was the most often reported reason for discontinuation in media reports $(44.9 \%)$ for this study. Therefore the primary reasons reported for the discontinuation of athletic teams in news articles in this current study were consistent with the top reasons provided by athletic administrators in the prior research.

While Title IX compliance was one of the primary reasons given in media reports, it was not the second most prevalent reason given, as it was by the athletic administrators in Skolnick's (2011) study. The second most prevalent reason found in media reports was the reallocation of athletics resources, which was cited nearly as often as reductions in athletic spending. This is consistent with the athletic administrators citing the financial strain of individual programs found in the Skolnick (2011) study. Title IX compliance was the third most prevalent factor cited in media reports in this study and was cited much less often than efforts to reduce athletic spending and the reallocation of athletics resources.

The most interesting finding in regard to the primary reasons for the discontinuation of athletic teams was the difference in the prevalence of Title IX compliance in the media reports in the current study and in the responses from athletic administrators. Title IX compliance and gender equity implications were reported by athletic administrators at very similar rates as athletic department budget shortage, institutional financial constraints, and financial strain of individual programs (Skolnick, 2011). In media reports, however, Title IX compliance was cited less than half as frequently as efforts to reduce athletic spending and the reallocation of athletics resources. There are several possible explanations for this difference. One possible explanation is a difference in population. The athletic administrators 
surveyed were all at institutions that discontinued at least three athletic teams while news reports were examined for institutions that discontinued at least one athletic team. Another possible explanation relates to small sample size. The most intriguing possible explanation, however, is a reluctance of athletic administrators to publicly report Title IX compliance as a reason for the discontinuation of athletic teams. This could relate in part to a 2003 report from the Office of Civil Rights that called the practice of discontinuing men's athletics teams to achieve Title IX compliance a disfavored practice ("Further Clarification", 2003).

\section{Participatory Data}

Anytime athletic programs are eliminated, some student-athletes are going to lose their opportunity to participate in intercollegiate athletics. What is clear from the data in this study is that men are disproportionately affected by these cuts. Among all 49 institutions in this study, the mean loss of opportunities for men was more than three times that of women. As expected, the most drastic difference is found in institutions citing Title IX compliance as a primary reason for the discontinuations. Despite the Office of Civil Rights' classification of opportunity elimination for men a "disfavored practice," ("Further Clarification", 2003) these institutions experienced drastic losses of athletic opportunities for men. It is also important to recognize that these are the losses of current opportunities. Title IX was enacted to address the lack of opportunities for women, and the loss of opportunities for women shown in this study, including losses at institutions specifically citing Title IX compliance as a reason for cuts, signifies a regression in efforts to provide women with opportunities that have historically been lacking.

\section{Stated Reasons vs. Actual Results Institutions Citing Efforts to Reduce Athletics Spending}

A total of 22 institutions identified efforts to reduce athletics spending as a primary reason for the discontinuation of athletics teams. These institutions experiences multi-million dollar increases in total athletic expenses after the discontinuation of athletic teams. This is certainly not indicative of a reduction in athletic spending, however, a comparison to national trends revels some slight success in frugality. In his report, Daniel Fulks (2010) shows that athletics expenses are increasing at a higher rate than revenue generated by athletics. The 22 institutions citing efforts to reduce athletic spending reported a percentage increase in mean athletic revenues of nearly twice the percent increase in mean athletic expenses. This is a stark contrast to the national trend reported by Fulks. While these institutions were not able to reduce their spending, their ability to reduce the rate of budget growth should be noted.

It is also interesting to note that the mean increase in total athletic revenue was $\$ 912,268$ more than the mean increase in total athletic expenses. With nearly $\$ 1,000,000$ in newly generated excess revenue, was the discontinuation of the athletic teams necessary? Could the athletic department have maintained the team or teams and still met their bottom line? Where 
is this excess revenue going? At the same time, the increases in revenue generated by the football, men's, and women's basketball programs all outpaced the increases in expenses for each respective program. Perhaps these institutions were just looking for a little budgetary breathing room, but is it worth sacrificing the student-athlete experience for the people affected?

\section{Institutions Citing Reallocation of Athletic Resources}

All but one of the NCAA Division I institutions included in this study, Grand Canyon University, were non-profit institutions (New, 2014). This means that there is little incentive to having program expenses lagging behind revenues. Most athletic departments align their spending to utilize nearly every dollar that they make. When an institution makes the decision to eliminate one or more of its athletic programs, the money not being spent on the eliminated programs is going to be spent elsewhere within the athletic department. This was evident in the consistency in the increases in total revenue and total expenses shown by the institutions in this study. The question then becomes to where is the money being reallocated?

Among the 21 institutions citing the reallocation of athletic resources, over $60 \%$ of the increase in total athletic expenses was allocated to football and men's basketball programs. This shows that the primary beneficiaries of the discontinuation of athletic teams are often the primary revenue producers and spectator attractions.

\section{Institutions Citing Title IX Compliance}

A total of nine institutions identified Title IX compliance as a primary reason for the discontinuation of athletics teams. Although schools have three ways to prove they are in compliance with the effective accommodation requirement, this study focused on the substantial proportionality test for Title IX compliance. Previously described as a "safe harbor," the proportionality test is a way that institutions can show mathematically that they are not discriminating between men and women. It is assumed that if the ratio of female student athletes closely mirrors that of the ratio of females in the student body that gender equality in participation opportunities is being met, even if there are significant numbers of women denied participation (Carpenter, 2013). While institutions identifying Title IX compliance as a primary factor for the elimination of athletic programs have made progress in the area of substantial proportionality, the progress made still leaves the institutions well short of compliance. None of the institutions achieved direct substantial proportionality. Based on these findings, institutions seeking Title IX compliance through the discontinuation of athletic teams were consistently failing to meet their stated goal. It is also important to note that schools that chose to cut men's teams but did not satisfy proportionality are also not likely to show Title IX compliance under the second prong for showing a history of program expansion of opportunities for the underrepresented sex. Although cutting men's teams helped to reduce the proportionality gap by an average of four percent, nothing about cutting men's teams 
actually increased opportunities for women in this sample.

Of the nine institutions citing Title IX compliance as a factor for the elimination of athletic teams, five were FBS programs and four were FCS programs. All nine institutions had football programs and the presence of a football program makes achieving Title IX compliance through proportionality very difficult as it would take approximately 5-6 women's teams to equal the number of participation opportunities provided by a football program. These challenges to achieving direct proportionality are also exemplified by Fulks (2013) noting that from 2004-2012 FBS programs averaged $330(55.0 \%)$ male student-athletes and $270(45.0 \%)$ female student-athletes. FCS programs averaged $287(56.9 \%)$ male student-athletes and 217 (43.1\%) female student-athletes and Division I programs without football averaged 167 (49.4\%) male student-athletes and $171(50.6 \%)$ female student-athletes.

It is also of note that institutions identifying Title IX compliance as a primary factor for the discontinuation of athletic teams saw large increases in their football and men's basketball related expenses. The increases in football and men's basketball spending accounted for more than half of all new spending. This means that the institutions were neither becoming proportionate in participation numbers nor were they spending a higher percentage of their budgets on women's programs. These outcomes are not in line with the letter or the spirit of Title IX.

The results of this study indicate that regardless of the publicly stated reasons for the discontinuation of athletic teams, the end result is reallocation of resources and that typically means more resources for the revenue producers.

\section{Limitations}

Although this current investigation revealed numerous areas of significant findings, there are several limitations within the design of this research that should temper the application of the results. First, this study was conducted using information and data from news outlets and the EADA Cutting Tool. It was assumed that the information reported in the media was accurate. To further bolster sources related to that assumption only reports from institutional websites or news reports with quotes from university officials were used; however, it is not possible to be completely certain that all of the news reports were accurate. All of the financial and participatory data was collected from the EADA archives. The EADA does not require standardized accounting practices and the accuracy of the data is reliant upon the accurate reporting from each institution. This study was also limited by the loss of archived information on websites. During the time frame of the study, many institutions changed the platform for their athletic webpages and in many cases this resulted in the loss of archived stories. This made retrieving information about the stated reasons for the discontinuation of the athletic teams more difficult for the older discontinuations.

\section{Conclusion}

The decision to discontinue an athletic team is difficult and complex, particularly during uncertain economic times. When 
making these decisions, it is important that administrators have as much information as possible. It is important to evaluate the outcomes of previous cuts to enhance the ability of athletic administrators to make future decisions. This study showed that the discontinuation of athletic teams for the purposes of a reduction in athletic spending or trying to achieve Title IX compliance was not effective. The most likely outcome from the discontinuation of one or more athletic teams was an increase in the football and basketball budgets and this appeared to be the desired result for many of the athletic programs in this study. The results of this study calls into question the validity of the publicly stated rationales for the discontinuations. Are these institutions simply failing to achieve their desired outcomes or are they providing rhetoric in the media to deflect attention from unpopular decisions? In any situation where the possibility of discontinuing an athletic team is present, it is vitally important that administrators understand the likelihood of achieving the desired outcome. It is important that the outcomes of these difficult decisions are closely examined by administrators at each school as well as by academicians across a broader scope of multiple schools. The outcomes should not only be evaluated, but the results should be shared in order to make future decisions of program elimination more informed. The loss of opportunities for student-athletes is too great a price to pay for misinformed or uninformed decisions.

\section{Future Research}

As this study serves as the initial inquiry to assess the connection between the rationale for team elimination and measureable outcomes, these results do provide an important basis for additional study. Future research should focus on examining the rationales and outcomes of the discontinuation of athletic teams at differing levels such as NCAA Division II, Division III, or the National Association of Intercollegiate Athletics (NAIA) institutions. Research also needs to examine the outcomes of discontinuations on a sport by sport basis that may identify specific trends and unique factors that may be tied to specific sports. By examining the discontinuation of athletic teams by sport, researchers could also identify the financial impact of eliminating each sport. This would provide administrators with valuable information in the process of determining which sport(s) to discontinue. Additionally, the relationship of the discontinuation of athletic teams to the level of institutional support received by the athletic department should be examined. The elimination of sport programs and participation opportunities for individuals is indeed a difficult and often controversial process, and the development of research findings that can better inform those decisions is critical. 


\section{References}

A Policy Interpretation: Title IX and Intercollegiate Athletics; Federal Register (1979) Vol. 44, No. 239.

Associated Press. (2010). NCAA report:

Economy cuts into sports. Retrieved from

http://sports.espn.go.com/ncf/news / story?id $=5490686$

Brady, E. (2009). Recession forces colleges to find ways to cut spending. USA Today. Retrieved from http://www.usatoday.com/sports/co llege/2009-02-18-colleges-economycover_N.htm

Carpenter, L. J. (2013). Gender equity: Opportunities to participate. In D. Cotton \& J. Wolohan, Law for Recreation and Sport Managers, $6^{\text {th }} \mathrm{ed}$. (pp. 526-534). Dubuque, IA: Kendall Hunt Publishing Company.

Civil Rights Restoration Act (1987). U.S.

G.P.O Supt. of Docs. Washington D.C.

Cohen v. Brown University, 991 F. 2d 888, 896 ( $1^{\text {st }}$ Cir. 1993).

Equity in Athletics Disclosure Act (1994).

20 U.S.C. \1092; 34 C.F.R. SS 668.41 and 668.47;

http://www2.ed.gov/finaid/prof/res ources/athletics/eada.html

Fulks, D. (2010). NCAA revenues \& expenses 2004-2009: NCAA Division I intercollegiate athletics programs report. Lexington, $\mathrm{KY}$.

Fulks, D. (2013). NCAA revenues \& expenses 2004-2012: NCAA Division I intercollegiate athletics programs report. Lexington, KY.

Further clarification of intercollegiate athletics policy guidance regarding Title IX compliance, (2003, July 11). Retrieved from http://www2.ed.gov/about/offices/1 ist/ocr/title9guidanceFinal.html Jamrisko, M., \& Kolet, I. (2014). College tuition costs soar: Chart of the day. Bloomberg Business. Retrieved from http://www.bloomberg.com/news/a rticles/2014-08-18/college-tuitioncosts-soar-chart-of-the-day

Law v. NCAA, 134 F.3d 1010 (10th Cir. 1998).

Liberty to reclassify wrestling program. (2011). Retrieved from http://www.libertyflames.com/index .cfm?PID $=10869 \&$ NewsID $=6907$

National Collegiate Athletic Association. (2015). Division I Manual 2015-2016. Indianapolis, IN.

New, J. (2014). NCAA limits on for-profits. Inside Higher Ed. Retrieved from https://www.insidehighered.com/ne ws/2014/08/14/ncaa-hopes-createprofit-classification

Olney, M., \& Pacitti, A. (2015). The rise of services and the lengthening of economic recovery. Berkley Economic History Laboratory. Retrieved from http://behl.berkeley.edu/files/2015/ 07/Olney-and-Pacitti-2015_WP201304-.pdf

Skolnick, J. (2011). Trimming teams: An examination of decision making processes in 
intercollegiate atbletic departments when

multiple varsity sport programs are

eliminated (Unpublished master's

thesis). University of North Carolina.

Chapel Hill, NC.

Temple reduces varsity sports from 24 to

17. (2013). Retrieved from

http://owlsports.com/news/2013/1

2/6/GEN_1206130910.aspx?path=g

eneral

Watson, G. (2009). Programs in precarious

position. ESPN. Retrieved from

http://espn.go.com/espn/print?id=4

313320\& type $=$ story

Wrestling, gymnastics programs terminated.

(2011). Retrieved from

http://www.fullertontitans.com/spor

ts/m-wrestl/spec-

$\mathrm{rel} / 040811 \mathrm{aab} . \mathrm{html}$

Journal of Amateur Sport Special Issue: Political Economy Marsh et al., 2016 


\section{Tables}

Table 1

Revenues and Expenses for Division I Football Bowl Subdivision Institutions

\begin{tabular}{lllll} 
Year & Revenues & Change & Expenses & Change \\
\hdashline 2012 & $55,976,000$ & $6.2 \%$ & $56,265,000$ & $10.8 \%$ \\
2011 & $52,715,000$ & $9.1 \%$ & $50,774,000$ & $8.8 \%$ \\
2010 & $48,298,000$ & $5.7 \%$ & $46,688,000$ & $1.7 \%$ \\
2009 & $45,698,000$ & $11.2 \%$ & $45,887,000$ & $10.9 \%$ \\
2008 & $41,088,000$ & $9.4 \%$ & $41,363,000$ & $5.5 \%$ \\
2007 & $37,566,000$ & $6.1 \%$ & $39,192,000$ & $9.6 \%$ \\
2006 & $35,400,000$ & $7.6 \%$ & $35,756,000$ & $14.9 \%$ \\
2005 & $32,849,000$ & $16.6 \%$ & $31,128,000$ & $7.4 \%$ \\
2004 & $28,214,000$ & $\mathrm{~N} / \mathrm{A}$ & $28,991,000$ & $\mathrm{~N} / \mathrm{A}$ \\
\hline
\end{tabular}

Note: Adapted from "NCAA Revenues \& Expenses 2004-2012: NCAA Division I Intercollegiate Athletics Programs Report." by D. Fulks, 2013.

Table 2

Revenues and Expenses for Division I Football Championship Subdivision Institutions

\begin{tabular}{lllll} 
Year & Revenues & Change & Expenses & Change \\
\hline 2012 & $13,761,000$ & $2.5 \%$ & $14,115,000$ & $6.8 \%$ \\
2011 & $13,425,000$ & $1.8 \%$ & $13,218,000$ & $1.0 \%$ \\
2010 & $13,189,000$ & $8.9 \%$ & $13,091,000$ & $8.9 \%$ \\
2009 & $12,111,000$ & $0.3 \%$ & $12,019,000$ & $-0.8 \%$ \\
2008 & $12,080,000$ & $14.8 \%$ & $12,115,000$ & $14.9 \%$ \\
2007 & $10,527,000$ & $9.2 \%$ & $10,541,000$ & $11.1 \%$ \\
2006 & $9,642,000$ & $7.1 \%$ & $9,485,000$ & $9.6 \%$ \\
2005 & $9,007,000$ & $15.9 \%$ & $8,655,000$ & $10.8 \%$ \\
2004 & $7,770,000$ & N/A & $7,810,000$ & N/A
\end{tabular}

Note: Adapted from "NCAA Revenues \& Expenses 2004-2012: NCAA Division I Intercollegiate Athletics Programs Report.” by D. Fulks, 2013. 
Table 3

Revenues and Expenses for Division I Institutions without Football

\begin{tabular}{lllll} 
Year & Revenues & Change & Expenses & Change \\
\hdashline 2012 & $12,756,000$ & $7.8 \%$ & $12,583,000$ & $8.8 \%$ \\
2011 & $11,831,000$ & $6.8 \%$ & $11,930,000$ & $3.2 \%$ \\
2010 & $11,077,000$ & $6.7 \%$ & $11,562,000$ & $10.1 \%$ \\
2009 & $10,382,000$ & $3.0 \%$ & $10,502,000$ & $1.5 \%$ \\
2008 & $10,082,000$ & $8.6 \%$ & $10,347,000$ & $10.0 \%$ \\
2007 & $9,281,000$ & $5.8 \%$ & $9,403,000$ & $5.4 \%$ \\
2006 & $8,771,000$ & $9.1 \%$ & $8,918,000$ & $12.4 \%$ \\
2005 & $8,036,000$ & $10.4 \%$ & $7,931,000$ & $11.0 \%$ \\
2004 & $7,281,000$ & $\mathrm{~N} / \mathrm{A}$ & $7,147,000$ & $\mathrm{~N} / \mathrm{A}$ \\
\hline
\end{tabular}

Note: Adapted from "NCAA Revenues \& Expenses 2004-2012: NCAA Division I Intercollegiate Athletics Programs Report.” by D. Fulks, 2013.

Table 4

Top Revenue Sources and Expenses for Division I Institutions

\begin{tabular}{lccc} 
& FBS & FCS & $\begin{array}{c}\text { D-I } \\
\text { Non-Football }\end{array}$ \\
\hline $\begin{array}{l}\text { Top Revenue Sources } \\
\text { Institutional Support }\end{array}$ & $19 \%$ & $70 \%$ & $77 \%$ \\
Ticket Sales & $22 \%$ & $5 \%$ & $4 \%$ \\
Cash Contributions & $21 \%$ & $8 \%$ & $6 \%$ \\
NCAA/Conference & $18 \%$ & $5 \%$ & $4 \%$ \\
Distributions & & & \\
Top Expenses & $34 \%$ & $31 \%$ & $32 \%$ \\
Salaries and Benefits & $15 \%$ & $26 \%$ & $29 \%$ \\
Grant-in-aids & &
\end{tabular}

Journal of Amateur Sport Special Issue: Political Economy Marsh et al., 2016 
Table 5

Eliminated Programs by Gender

\begin{tabular}{|c|c|c|c|c|c|}
\hline Year & $\begin{array}{c}\text { Number of } \\
\text { Schools }\end{array}$ & $\begin{array}{c}\text { Eliminated } \\
\text { Men's } \\
\text { Programs }\end{array}$ & $\begin{array}{l}\text { Eliminated } \\
\text { Women's } \\
\text { Programs }\end{array}$ & $\begin{array}{c}\text { Eliminated } \\
\text { Co-Ed } \\
\text { Programs }\end{array}$ & $\begin{array}{c}\text { Total } \\
\text { Eliminated } \\
\text { Programs }\end{array}$ \\
\hline $2001-2002$ & 3 & 4 & 2 & 0 & 6 \\
\hline $2002-2003$ & 3 & 6 & 2 & 1 & 9 \\
\hline 2003-2004 & 5 & 6 & 1 & 0 & 7 \\
\hline 2004-2005 & 4 & 7 & 2 & 0 & 9 \\
\hline 2005-2006 & 6 & 5 & 1 & 0 & 6 \\
\hline 2006-2007 & 7 & 16 & 6 & 1 & 23 \\
\hline 2007-2008 & 8 & 8 & 2 & 0 & 10 \\
\hline 2008-2009 & 13 & 14 & 10 & 1 & 25 \\
\hline Total & 49 & 66 & 26 & 3 & 95 \\
\hline
\end{tabular}

Table 6

Eliminated Programs by Number of Programs Eliminated at Each Institution

\begin{tabular}{ccccccc} 
Year & $\begin{array}{c}\text { Schools } \\
\text { Eliminating } \\
\text { 1 Program }\end{array}$ & $\begin{array}{c}\text { Schools } \\
\text { Eliminating } \\
\text { 2 Program }\end{array}$ & $\begin{array}{c}\text { Schools } \\
\text { Eliminating } \\
\text { 3 Programs }\end{array}$ & $\begin{array}{c}\text { Schools } \\
\text { Eliminating } \\
\text { 5 Programs }\end{array}$ & $\begin{array}{c}\text { Schools } \\
\text { Eliminating }\end{array}$ & $\begin{array}{c}\text { S Programs } \\
\text { Eliminating }\end{array}$ \\
\hline $2001-2002$ & 1 & 1 & 1 & 0 & 0 & 0 \\
$2002-2003$ & 1 & 1 & 0 & 0 & 1 & 0 \\
$2003-2004$ & 3 & 2 & 0 & 0 & 0 & 0 \\
$2004-2005$ & 0 & 3 & 1 & 0 & 0 & 0 \\
$2005-2006$ & 6 & 0 & 0 & 0 & 0 & 0 \\
$2006-2007$ & 3 & 1 & 1 & 1 & 0 & 1 \\
$2007-2008$ & 7 & 0 & 1 & 0 & 0 & 0 \\
$2008-2009$ & 5 & 6 & 1 & 1 & 0 & 0 \\
Total & 26 & 14 & 5 & 2 & 1 & 1 \\
\hline
\end{tabular}

Journal of Amateur Sport Special Issue: Political Economy Marsh et al., 2016 
Table 7

Mean Participation Numbers

\begin{tabular}{|c|c|c|c|c|}
\hline & $\begin{array}{l}\text { All Institutions } \\
\quad(n=49)\end{array}$ & $\begin{array}{l}\text { Citing } \\
\text { Reallocation } \\
(n=21)\end{array}$ & $\begin{array}{l}\text { Citing Reduce } \\
\text { Spending } \\
(n=22)\end{array}$ & $\begin{array}{c}\text { Citing Title IX } \\
\text { Compliance } \\
(n=9)\end{array}$ \\
\hline $\begin{array}{l}\text { Male S-As } \\
\text { Year Prior }\end{array}$ & 235 & 200 & 262 & 261 \\
\hline $\begin{array}{l}\text { Male S-As } \\
\text { Year After }\end{array}$ & 200 & 177 & 225 & 209 \\
\hline Change & 35 & 23 & 37 & 52 \\
\hline$t$-Value & $4.499 * *$ & $2.461^{*}$ & $3.332^{* *}$ & $3.003^{*}$ \\
\hline $\begin{array}{c}\text { Female S-As } \\
\text { Year Prior }\end{array}$ & 173 & 140 & 191 & 187 \\
\hline $\begin{array}{c}\text { Female S-As } \\
\text { Year After }\end{array}$ & 163 & 137 & 183 & 181 \\
\hline Change & 10 & 3 & 8 & 6 \\
\hline$t$-Value & 1.346 & 0.726 & 0.562 & 0.614 \\
\hline
\end{tabular}

Journal of Amateur Sport Special Issue: Political Economy Marsh et al., 2016 
Table 8

Mean Revenues and Expenses for All Institutions

\begin{tabular}{|c|c|c|c|c|}
\hline & $\begin{array}{c}\text { Year Prior to } \\
\text { Discontinuation }\end{array}$ & $\begin{array}{l}\text { Year After } \\
\text { Discontinuation }\end{array}$ & Change & $t$-V alue \\
\hline Total Revenue & $\$ 15,041,638$ & $\$ 17,187,893$ & $\$ 2,146,255$ & $3.866 * *$ \\
\hline Total Expenses & $\$ 14,618,807$ & $\$ 16,721,937$ & $\$ 2,103,130$ & $6.215^{* *}$ \\
\hline Football Revenue & $\$ 5,558,307$ & $\$ 6,744,686$ & $\$ 1,186,379$ & $3.036 * *$ \\
\hline Football Expenses & $\$ 4,546,505$ & $\$ 5,300,145$ & $\$ 753,640$ & $3.377 * *$ \\
\hline $\begin{array}{l}\text { Men's Basketball } \\
\text { Revenue }\end{array}$ & $\$ 1,616,900$ & $\$ 2,062,250$ & $\$ 445,350$ & 1.842 \\
\hline $\begin{array}{l}\text { Men's Basketball } \\
\text { Expenses }\end{array}$ & $\$ 1,460,571$ & $\$ 1,657,990$ & $\$ 197,329$ & $5.148 * *$ \\
\hline $\begin{array}{l}\text { Women's Basketball } \\
\text { Revenue }\end{array}$ & $\$ 618,735$ & $\$ 742,070$ & $\$ 123,335$ & $2.359 *$ \\
\hline $\begin{array}{l}\text { Women's Basketball } \\
\text { Expenses }\end{array}$ & $\$ 979,239$ & $\$ 1,125,063$ & $\$ 145,824$ & $4.266 * *$ \\
\hline
\end{tabular}

Journal of Amateur Sport Special Issue: Political Economy Marsh et al., 2016 
Table 9

Mean Revenues and Expenses for Institutions Citing Reduction in Atbletic Spending

\begin{tabular}{|c|c|c|c|c|}
\hline & $\begin{array}{r}\text { Year Prior to } \\
\text { Discontinuation }\end{array}$ & $\begin{array}{c}\text { Year After } \\
\text { Discontinuation }\end{array}$ & Change & $t$-V alue \\
\hline Total Revenue & $\$ 17,021,087$ & $\$ 19,948,831$ & $\$ 2,927,744$ & $4.072 * *$ \\
\hline Total Expenses & $\$ 17,085,735$ & $\$ 19,101,211$ & $\$ 2,015,476$ & $4.019 * *$ \\
\hline Football Revenue & $\$ 7,201,048$ & $\$ 8,589,761$ & $\$ 1,388,713$ & $2.296 *$ \\
\hline Football Expenses & $\$ 5,503,368$ & $\$ 6,090,360$ & $\$ 586,992$ & 1.758 \\
\hline $\begin{array}{l}\text { Men's Basketball } \\
\text { Revenue }\end{array}$ & $\$ 1,961,083$ & $\$ 2,648,044$ & $\$ 686,961$ & 1.315 \\
\hline $\begin{array}{l}\text { Men's Basketball } \\
\text { Expenses }\end{array}$ & $\$ 1,637,668$ & $\$ 1,762,056$ & $\$ 124,388$ & $2.192 *$ \\
\hline $\begin{array}{l}\text { Women's Basketball } \\
\text { Revenue }\end{array}$ & $\$ 685,315$ & $\$ 919,914$ & $\$ 234,599$ & $2.801 *$ \\
\hline $\begin{array}{l}\text { Women's Basketball } \\
\text { Expenses }\end{array}$ & $\$ 1,106,266$ & $\$ 1,211,724$ & $\$ 105,458$ & 1.744 \\
\hline
\end{tabular}


Table 10

Mean Revenues and Expenses for Institutions Citing Reallocation of Athletic Resources

\begin{tabular}{|c|c|c|c|c|}
\hline & $\begin{array}{r}\text { Year Prior to } \\
\text { Discontinuation }\end{array}$ & $\begin{array}{c}\text { Year After } \\
\text { Discontinuation }\end{array}$ & Change & $t$-V alue \\
\hline Total Revenue & $\$ 10,932,644$ & $\$ 13,154,151$ & $\$ 2,221,507$ & $3.920 * *$ \\
\hline Total Expenses & $\$ 10,841,581$ & $\$ 12,952,722$ & $\$ 2,111,141$ & $3.580 * *$ \\
\hline Football Revenue & $\$ 3,510,298$ & $\$ 4,917,340$ & $\$ 1,407,042$ & $2.188 *$ \\
\hline Football Expenses & $\$ 2,996,502$ & $\$ 4,009,217$ & $\$ 1,012,715$ & $2.489 *$ \\
\hline $\begin{array}{l}\text { Men's Basketball } \\
\text { Revenue }\end{array}$ & $\$ 1,148,843$ & $\$ 1,455,796$ & $\$ 306,953$ & $2.454 *$ \\
\hline $\begin{array}{l}\text { Men's Basketball } \\
\text { Expenses }\end{array}$ & $\$ 1,133,116$ & $\$ 1,397,616$ & $\$ 264,500$ & $4.512 * *$ \\
\hline $\begin{array}{l}\text { Women's Basketball } \\
\text { Revenue }\end{array}$ & $\$ 507,102$ & $\$ 582,237$ & $\$ 75,135$ & 1.105 \\
\hline $\begin{array}{l}\text { Women's Basketball } \\
\text { Expenses }\end{array}$ & $\$ 740,268$ & $\$ 906,211$ & $\$ 165,943$ & $3.739 * *$ \\
\hline
\end{tabular}

Journal of Amateur Sport Special Issue: Political Economy Marsh et al., 2016 
Table 11

Mean Revenues and Expenses for Institutions Citing Title IX Compliance

\begin{tabular}{|c|c|c|c|c|}
\hline & $\begin{array}{c}\text { Year Prior to } \\
\text { Discontinuation }\end{array}$ & $\begin{array}{c}\text { Year After } \\
\text { Discontinuation }\end{array}$ & Change & $t$-V alue \\
\hline Total Revenue & $\$ 19,523,742$ & $\$ 22,729,100$ & $\$ 3,205,358$ & $3.052 *$ \\
\hline Total Expenses & $\$ 19,427,520$ & $\$ 22,493,012$ & $\$ 3,065,492$ & $3.011 *$ \\
\hline Football Revenue & $\$ 4,936,797$ & $\$ 6,818,007$ & $\$ 1,881,210$ & 1.922 \\
\hline Football Expenses & $\$ 5,174,567$ & $\$ 6,641,705$ & $\$ 1,467,138$ & 2.095 \\
\hline $\begin{array}{l}\text { Men's Basketball } \\
\text { Revenue }\end{array}$ & $\$ 1,921,448$ & $\$ 2,315,823$ & $\$ 394,375$ & $2.781 *$ \\
\hline $\begin{array}{l}\text { Men's Basketball } \\
\text { Expenses }\end{array}$ & $\$ 1,923,573$ & $\$ 2,174,177$ & $\$ 250,604$ & $3.069 *$ \\
\hline $\begin{array}{l}\text { Women's Basketball } \\
\text { Revenue }\end{array}$ & $\$ 899,373$ & $\$ 1,042,358$ & $\$ 142,985$ & 1.028 \\
\hline $\begin{array}{l}\text { Women's Basketball } \\
\text { Expenses }\end{array}$ & $\$ 1,355,854$ & $\$ 1,599,984$ & $\$ 244,130$ & 2.211 \\
\hline
\end{tabular}

Journal of Amateur Sport Special Issue: Political Economy Marsh et al., 2016 